patient-centred approach to CPD and revalidation. Informed by innovative and robust research, a more rational debate can ensue. Honesty about the true cost, skills needed, and consequences is paramount. Postgraduate medical education has the chance to rise to the challenge of balancing regulatory needs with a healthy curiosity.

\section{Murray Lough,}

Lead (Educational Research), NHS Education for Scotland, Glasgow

\section{Provenance}

Commissioned; not peer reviewed

\section{REFERENCES}

1. Secretary of State for Health. Trust, assurance and safety - the regulation of health professionals in the 21st century. CM7013. London: The Stationery Office, 2007.

2. NHS Evidence. http://www.evidence.nhs.uk (accessed 8 Jul 2009).

3. Knowledge for Care Scotland. http://www.knowledge.scot.nhs.uk (accessed $8 \mathrm{Jul}$ 2009)

4. Cook DA, Levinson AJ, Garside S, et al. Internet-based learning in the health professions: a meta-analysis. JAMA 2008; 300: 1181-1196.

5. Eva KW, Hatela RM, Le Blanc VR, Brookes LR. Teaching from the clinical reasoning literature: Combined reasoning strategies help not with diagnosticians overcome misleading information. Med Educ 2007 41(12): 1152-1158.

6. Scott IA. Errors in clinical reasoning: causes and remedial strategies. BMJ 2009; 338: b1860.

7. Todres M, Stephenson A, Jones R. Medical education research remains the poor relation. BMJ 2007; 335: 333-335.

8. Doumit G, Gattellari M, Grimshaw J, O'Brien MA. Local opinion leaders: effects on professional practice and healthcare outcomes. Cochrane Database Syst Rev 2007; 1: CD000125.

9. O'Brien MA, Rogers S, Jamtvedt G, et al. Educational outreach visits: effects on professional practice and healthcare outcomes. Cochrane Database Syst Rev 2007; 4: CD000409.

10. Forsetlund L, Bjorndal A, Rashidian A, et al. Continuing educational meetings and workshops: effects on

professional practice and healthcare outcomes. Cochrane Database Syst Rev 2009; 2: CD003030.

11. Irvine D. The performance of doctors. I: professionalism and self-regulation in a changing world. BMJ 1997; 314: 1540-1542.

DOI: 10.3399/bjgp09X453738

ADDRESS FOR CORRESPONDENCE

\section{Murray Lough}

NHS Education for Scotland, 89 Hydepark Street, Glasgow, G3 8BW E-mail: murray.lough@nes.scot.nhs.uk

\title{
Being a good clinician is not enough: doctors as employers and practices as organisations
}

It is now accepted in general practice that we should incorporate the evidence derived from biomedical research into our practice, and both current contractual and proposed governance arrangements are designed to encourage this.

The paper in this issue of the BJGP by Hewitt et $a l^{1}$ reminds us of the additional importance of applying evidence to the overall service that we provide as well as to the narrow medical content of our consultations. Focusing on the detail of receptionist-patient interactions, Hewitt and her co-authors point to some of the contexts in which misunderstanding, miscommunication, and ultimately dissatisfaction may arise. They demonstrate that receptionists tend to use a limited repertoire of styles of communication, and that some of these styles are more prone than others to generate misunderstandings or miscommunications. This is important because such miscommunications, especially if repeated in subsequent visits to the practice, may build up to generate significant patient dissatisfaction; in the competitive environment currently facing general practice this could become a real problem.

The obvious approach to address this danger would be via staff training, and the paper by Hewitt et al ${ }^{1}$ could nicely be used as a teaching aid for in-house reception training; seeing dysfunctional exchanges written down can be very enlightening.

This draws attention to a wider issue: clinician-patient interactions do not represent the totality - or even the most important part of - a patient's overall interactions with the practice, and this is something that should be taken into account by partners as practice owners. Negotiation with receptionists, requests for repeat prescriptions, discussions with secretaries about Choose and Book appointments: all these represent opportunities for good or bad patient experiences.

As the complexity of the care that we provide increases, modern general practices have become quite large organisations, with a significant number of employees, and I would argue that we can no longer get away with simply appointing a practice manager and delegating staff training to that role. Issues such as violence against staff (see the article by Magin et al in this issue of the $B J G P^{2}$ ) and the stresses that receptionists experience $^{3}$ are important topics that partners should consider when they think about the development of their staff. Furthermore, just as we look for evidence about the clinical care that we provide, so we should engage with the extensive literature about behaviour in organisations to garner ideas about how this should be done.

The discourse analysis method used in Hewitt et al's study reminds us that if we 
are to take seriously the 'evidence base' relating to service delivery by general practices as organisations, we must also be prepared to engage across disciplines with types of research that we may find unfamiliar; randomised controlled trials (RCTs) are not necessarily the best approach to problems such as these, ${ }^{4}$ and we must be both open minded to alternatives and prepared to engage critically with different research traditions.

The approach used by Hewitt et al is a good example of this. Discourse analysis emerged as a method from interactionist sociology, and it takes seriously the minutiae of communication, often integrating observational evidence with a detailed analysis of verbal exchanges. It has a 'long theoretical and research tradition's and has been used, for example, in studying doctor-patient interactions in both primary and secondary care (for example, see Atkinson ${ }^{6}$ ), revealing sometimes unpalatable truths about power relationships within the consultation. ${ }^{7}$

Getting to grips with this type of research requires us to engage with theory from social science disciplines, and this can be challenging. However, it can be done: a good example is a paper by Greenhalgh and colleagues, ${ }^{8}$ looking at interpreted consultations in general practice. Led by a practising GP, and using the concept of 'organisational routines' as a theoretical framework from the discipline of organisational studies, the authors offer some interesting and practical suggestions for how the provision of interpreting services might be improved. Although the content has applicability to GPs, the paper was published in the journal Sociology of Health \& IIIness, and it is reasonable to suggest that this may limit its accessibility to most GPs.

There is much that is out there in the wider social science/organisational studies literature that might be useful to GPs as we strive to improve the service that we provide, but there is at present only limited crossover from these disciplines into general practice. A fixed idea of a 'hierarchy of evidence' with RCTs at the top may be part of the problem but there are also more practical issues to do with making social science theory accessible to a more general audience. Possible routes might be for general practice journals, such as the $B J G P$, to commission reviews of topics such as these in addition to more conventional systematic reviews of clinical subjects. The qualitative metasynthesis is a method that is gaining respectability, and it could provide a way forward. ${ }^{9}$

Also relating to the issue of organisational structure, the May issue of the $B J G P$ reminded us eloquently ${ }^{10-14}$ that we currently face many challenges, not least of which is the apparent breakdown of relationships between salaried GPs and partners. This is a complicated issue, with resentments on both sides, but I venture to suggest that a careful analysis of modern general practices as organisations, paying attention to power, relationships, and 'sensemaking'15,16 about what it means to be a GP might have something useful to add which could help us past the current impasse.

\section{Kath Checkland}

Walport Clinical Lecturer in Primary Care, Manchester University, National Primary Care Research Centre, Manchester, UK

\section{Provenance}

Commissioned; peer reviewed.

\section{REFERENCES}

1. Hewitt H, McCloughan L, McKinstry B. Front desk talk: a discourse analysis of receptionist-patient interaction. Br J Gen Pract 2009; 59(565): 571-577.

2. Magin P, Joyce T, Adams J, Goode S, Cotter G Receptionists' experiences of occupational violence in general practice: a qualitative study. Br J Gen Pract 2009; 59(565): 578-583.

3. Eisner M, Britten N. What do general practice receptionists think and feel about their work? $\mathrm{Br} J$ Gen Pract 1999; 49(439): 103-106.

4. Dean K. The role of methods in maintaining orthodox beliefs in health research. Soc Sci Med 2004; 58(4): 675-685.

5. Denzin NK, Lincoln YS. Methods of collecting and analyzing empirical materials. In: Denzin NK, Lincoln YS, eds. Collecting and interpreting qualitative materials. Thousand Oaks, CA: Sage, 1998.

6. Atkinson P. Medical talk and medical work. London: Sage, 1995.

7. Fisher S. Doctor-patient communication: a social and micro-political performance. Sociol Health Ill 1984; 6(1): 1-29.

8. Greenhalgh T, Voisey C, Robb N. Interpreted consultations as 'business as usual'? An analysis of organisational routines in general practices. Sociol Health Ill 2007; 29(6): 931-954.

9. Thorne S, Jensen L, Kearney MH, et al. Qualitative metasynthesis: reflections on methodological

orientation and ideological agenda. Qual Health Res 2004; 14(10): 1342-1365.

10. Lester H. A rose by any other name. Br J Gen Pract 2009; 59(562): 386.

11. Lakasing E. The rise of the medical McJob: why we should turn the clock back. Br J Gen Pract 2009; 59(562): 380-382.

12. Gubb JD. Commentary: unintended consequences: what of quality outside the QOF? Br J Gen Pract 2009; 59(562): e173-e174.

13. Gillies JC, Mercer SW, Lyon A, Scott M, Watt GC. Distilling the essence of general practice: a learning journey in progress. Br J Gen Pract 2009; 59(562): e167-e176.

14. Heath I. That by which it is what it is. Br J Gen Pract 2009; 59(562): e142-e143.

15. Weick KE. Sensemaking in organizations. Thousand Oaks, CA: Sage, 1995.

16. Checkland K. Understanding general practice: a conceptual framework from case studies in the UK NHS. Br J Gen Pract 2007; 57(534): 56-63.

DOI: 10.3399/bjgp09X453747

\section{ADDRESS FOR CORRESPONDENCE}

\section{Kath Checkland}

Manchester University, National Primary

Care Research Centre, 5th Floor

WIlliamson Bulding, Manchester,

M13 9PL, UK. E-mail:

Katherine.Checkland@manchester.ac.uk 